\title{
Communication
}

\section{A Novel Rhodopsin Analog with Bicyclic Retinal Involving the 8-18 Bonded Structure in the Chromophore}

\author{
Masayoshi ITO, ${ }^{*}$ Yoshiko MANTANI, Kiyoshi TsuKIDA, ${ }^{1}$ \\ Yoshinori SHICHIDA, Shinpei IOSHIDA, Yoshitaka FUKADA, \\ and Töru YoshizAWA ${ }^{2}$ \\ ${ }^{1}$ Kobe Women's College of Pharmacy, Motoyamakita-machi, \\ Higashinada-ku, Kobe 658, Japan \\ ${ }^{2}$ Department of Biophysics, Faculty of Science, Kyoto University, \\ Sakyo-ku, Kyoto 606, Japan \\ (Received September 12, 1988)
}

Key Words bicyclic rhodopsin analog, CD spectrum of rhodopsin, bicyclic retinal, twisted conformation, fixed retinylidene chromophore, conjugated cyclopentadiene system

As part of our ongoing investigations to clarify the primary process of vision by chemical means, the elucidation of the origin of the induced CD spectrum (Table 1) of rhodopsin (1) (Scheme 1) is of particular interest for the conformational analysis of the photobleaching intermediates of rhodopsin, because $\mathrm{CD}$ spectrum gives precise information about the interaction between retinylidene chromophore and protein moiety of (1) in the intermediates (1). In the previous paper (2), it had been chemically confirmed from the $\mathrm{CD}$ data (Table 1) of the rhodopsin analog (2) involving the 10-20 bonded structure that the $\alpha$-CD-band of $(\mathbf{1})$ is due to the twisted $12 \mathrm{~s}$-trans-conformation in the chromophore. This is strong evidence supporting the theory for twisted chromophore (3-5) proposed for the induction of $\alpha$-CD-band in (1). On the other hand, the rhodopsin analog (2) displayed a similar $\beta$-CD-band to that of (1), indicating that the $\beta$-CD-band is likely to be originated from a twisted conformation around the 6-7 single bond. This is also suggested in the case of the $\beta$ CD-band of 9-cis-rhodopsin (isorhodopsin) possessing 9-cis-retinal as its chromophore, because 9-cis-rhodopsin showed a similar $\beta$-CD-band (6) (Table 1) to that of (1) and the interaction between a $\beta$-ionone ring region of the chromophore and its binding site of opsin is similar in both pigments, (1) and isorhodopsin. Therefore, we synthesized the bicyclic rhodopsin analog-I (3) having the conformationally 6scis-fixed retinylidene chromophore and reported its CD data (7) (Table 1). Since the conjugated cyclopentadiene system in (3) was locked by the presence of a gem-

1 伊藤允好, 萬谷佳子, 月田 潔, ${ }^{2}$ 七田芳則, 吉田真平, 深田吉孝, 吉澤 透

* To whom all correspondence should be addressed. 

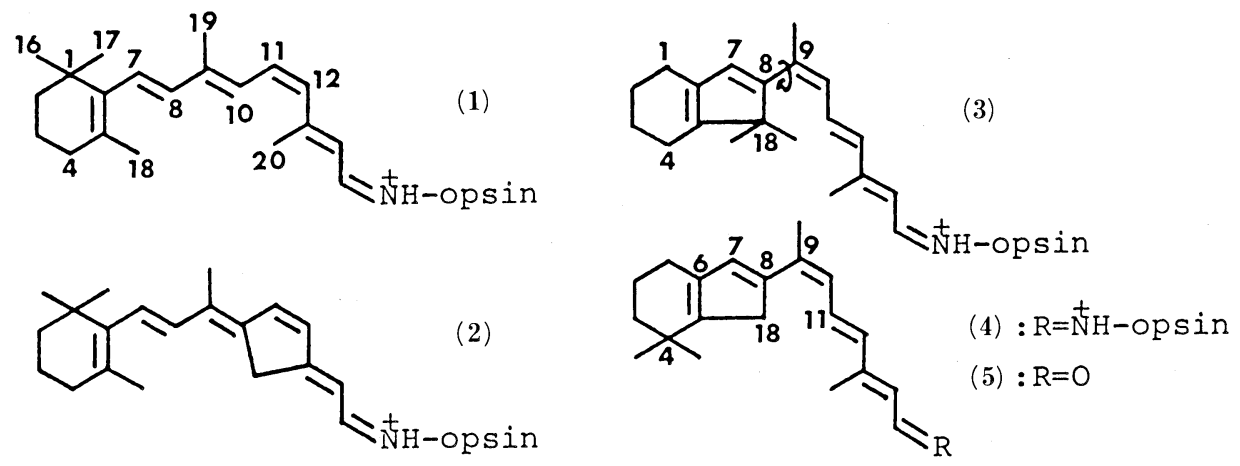

Scheme 1

Table 1. CD data of rhodopsin (1) and its analogs.

\begin{tabular}{cll}
\hline & \multicolumn{2}{c}{ CD data (nm) } \\
\cline { 2 - 3 } Pigments & \multicolumn{1}{c}{$\alpha$-Band } & \multicolumn{1}{c}{$\beta$-Band } \\
\hline (1) & $487(+7.5)^{\mathrm{a}}$ & $335(+15.4)$ \\
$(\mathbf{2})$ & negligible & $336(+11.6)$ \\
9-cis-Rhodopsin & $484(+8.9)$ & $335(+6.6)$ \\
$(\mathbf{3})$ & $527(+16)$ & $328(-8.2)$ \\
$(\mathbf{4})$ & $512(+13.6)$ & $326(-2.1)$ \\
\hline
\end{tabular}

${ }^{\mathrm{a}}$ Intensities in parentheses represent ellipticity (in mdeg/absorption).

dimethyl group at the 18-position, the bulkiness of which inversely caused the strong twist around the 8-9 single bond, resulting in the induction of negative $\beta$ CD-band in (3). We now report the synthesis and CD spectrum of a novel 9-cisbicyclic rhodopsin analog-II (4) whose chromophore consists of an 8-18 bonded retinal analog (5) without a gem-dimethyl group in the cyclopentadiene system.

Aldol condensation (LDA, THF, $-78 \sim-40^{\circ} \mathrm{C}$ ) of the bicyclic pentenone (6) (8) (Scheme 2) with the methyl ketone-acetal (7) gave the hydroxy-acetal (8) in $83 \%$ yield as a mixture $(1: 1)$ of diastereoisomers which, without separation, was deprotected to afford the hydroxy-aldehyde (9) in $80 \%$ yield. An Emmons-Horner reaction $\left(n-\mathrm{BuLi}, \mathrm{THF}, 0^{\circ} \mathrm{C}\right)$ of $(\mathbf{9})$ with the ester-phosphonate $(\mathbf{1 0})$ gave the dieneester (11) in $68 \%$ yield as a mixture of four isomers (13-trans- and-cis-isomers for each of the two diastereoisomers) which, without separation, after reduction of the ketone group with $\mathrm{LiBH}_{4}$ was dehydrated $\left(\mathrm{I}_{2}\right.$, pet. ether, reflux, $\left.1 \mathrm{~h}\right)$ to provide the conjugated pentaene-ester (12) in $20 \%$ yield. Conversion of the ester group in (12) to the aldehyde group led to a mixture of conjugated pentaene-aldehydes in $52 \%$ yield, the repeated purification of which by a combination of column chromatography and preparative HPLC in the dark furnished four bicyclic retinal isomers 

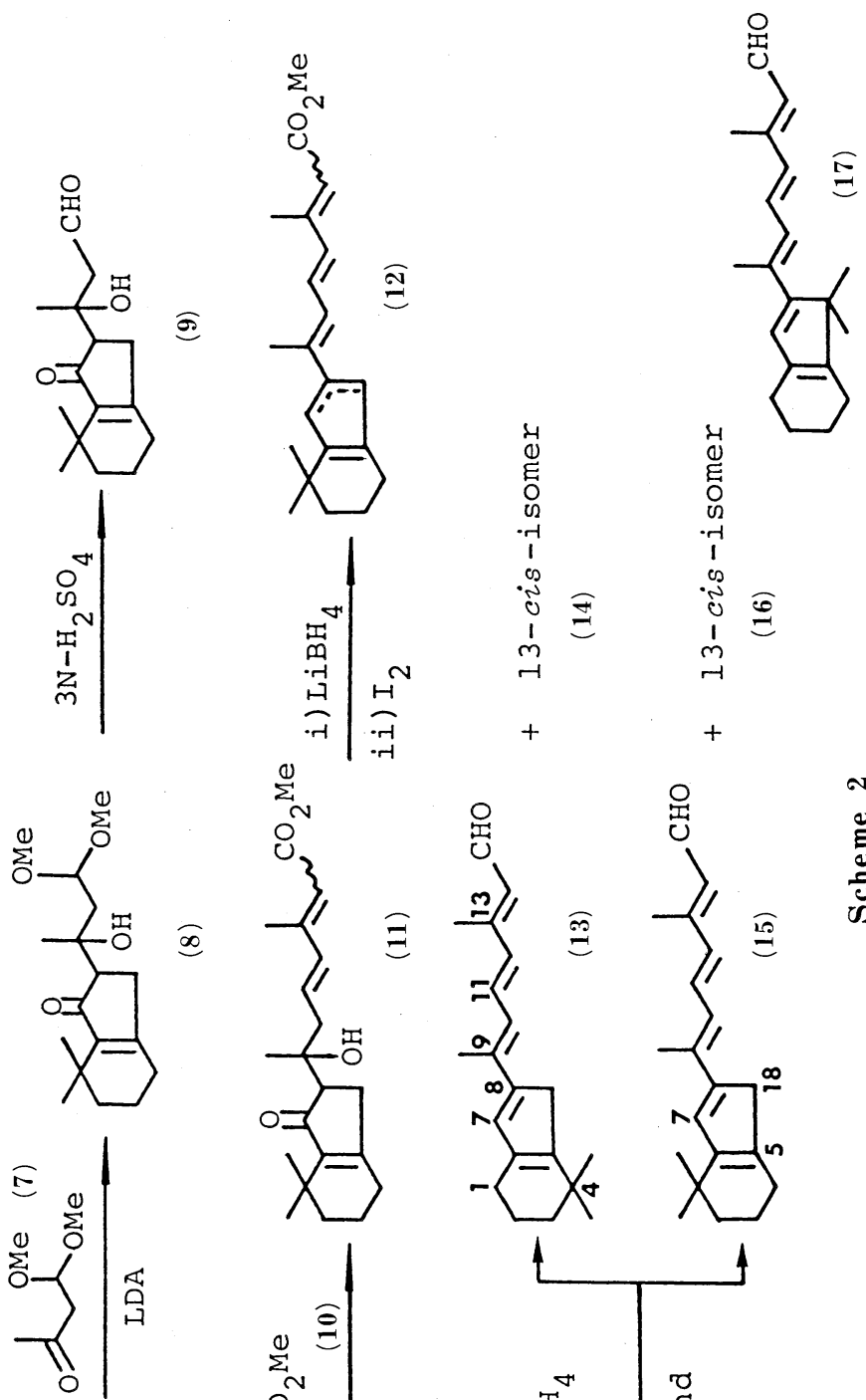

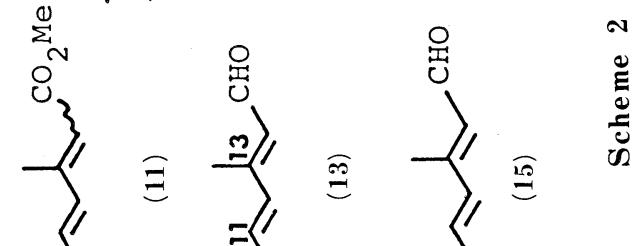

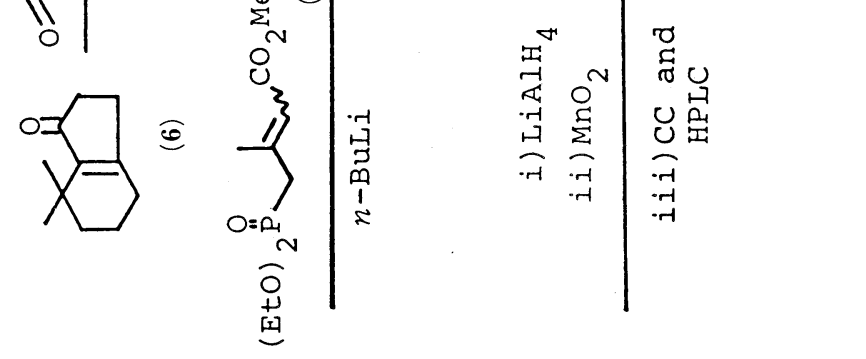


Table 2. Characteristic UV-VIS and ${ }^{1} \mathrm{H}-\mathrm{NMR}$ data for bicyclic retinals $(\mathbf{1 3}, \mathbf{1 5}$, and 17).

\begin{tabular}{|c|c|c|c|c|}
\hline & & \multicolumn{2}{|c|}{ Bicyclic retinal-II } & \multirow{2}{*}{$\begin{array}{l}\text { Bicyclic retinal-I } \\
\text { all-trans (17) }\end{array}$} \\
\hline & & all-trans $(\mathbf{1 3})$ & all-trans $(\mathbf{1 5})$ & \\
\hline \multirow{2}{*}{\multicolumn{2}{|c|}{ UV-VIS $\lambda_{\max }^{\mathrm{EtOH}} \mathrm{nm}$}} & $425(\varepsilon 32,000)$ & $425(\varepsilon 29,000)$ & $425(\varepsilon 33,100)$ \\
\hline & & $295(\varepsilon 10,000)$ & $295(\varepsilon 11,000)$ & $292(\varepsilon 8,300)$ \\
\hline \multirow{8}{*}{$\begin{array}{l}{ }^{1} \mathrm{H}-\mathrm{NMR} \\
\quad(200 \mathrm{MHz}) \\
\quad\left(\delta, \mathrm{CDCl}_{3}\right)\end{array}$} & 9-Me & $2.07(\mathrm{~s})$ & $2.09(\mathrm{~s})$ & $2.11(\mathrm{~s})$ \\
\hline & 13-Me & $2.33(\mathrm{~s})$ & $2.33(\mathrm{~s})$ & $2.34(\mathrm{~s})$ \\
\hline & $18-\mathrm{H}_{2}$ & 3.16 (brs) & $3.12($ sharp s) & - \\
\hline & $12-\mathrm{H}$ & $6.39(\mathrm{~d}, J=16)$ & $6.36(\mathrm{~d}, J=15)$ & $6.42(\mathrm{~d}, J=15)$ \\
\hline & $11-\mathrm{H}$ & $7.15(\mathrm{dd}, J=16,11.5)$ & $7.15(\mathrm{dd}, J=15,11.5)$ & $7.21(\mathrm{dd}, J=15,11)$ \\
\hline & $10-\mathrm{H}$ & $6.40(\mathrm{~d}, J=11.5)$ & $6.36(\mathrm{~d}, J=11.5)$ & $6.43(\mathrm{~d}, J=11)$ \\
\hline & $7-\mathrm{H}$ & $6.45(\mathrm{~s})$ & $6.63(\mathrm{~s})$ & $6.47(\mathrm{~s})$ \\
\hline & $\mathrm{CHO}$ & $10.10(\mathrm{~d}, J=8.5)$ & $10.10(\mathrm{~d}, J=8.5)$ & $10.10(\mathrm{~d}, J=8)$ \\
\hline
\end{tabular}

(13)

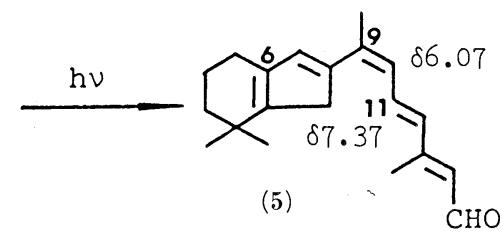

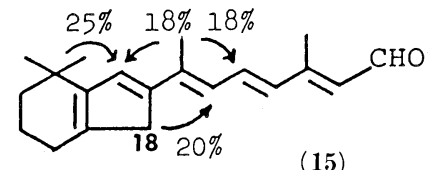

(15)

(13)

(15)
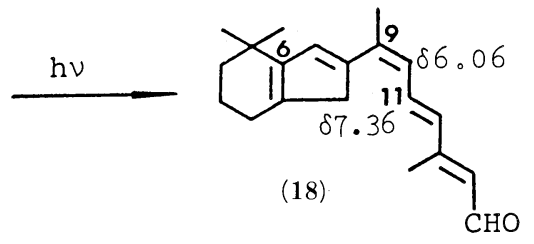

Scheme 4

$[(\mathbf{1 3}):(\mathbf{1 4}):(\mathbf{1 5}):(\mathbf{1 6})=1.2: 1.0: 1.7: 1.4]$. The structures of the isomers were determined on the basis of the UV-VIS and ${ }^{1} \mathrm{H}-\mathrm{NMR}$ spectral data (Table 2) compared with those (7) of another all-trans-bicyclic retinal (17) having a fixed conjugated pentaenal chromophore. Two bicyclic retinals (13 and 15) had absorption maximum values $(425 \mathrm{~nm})$ identical with that of $(17)$, showing that both possess the same chromophoric system as (17). Confirmation of their stereostructures was based on measurements of nuclear Overhauser effects (NOE) (Scheme 3). Irradiation of the two all-trans-bicyclic retinals (13 and 15) using a fluorescent lamp $(30 \mathrm{~W})$ in $\mathrm{MeOH}$ produced 9-cis-isomers (5 and 18) respectively (Scheme 4) in ca. $70 \%$ yield. The 9-cis-geometry for (5) and (18) was recognizable from the upfield 
shift of the 10-H signal and the downfield shift of the $11-\mathrm{H}$ signal in their ${ }^{1} \mathrm{H}-\mathrm{NMR}$ by comparison with those of all-trans-isomers (13 and 15)(9). Their UV-VIS absorption maxima $(417 \mathrm{~nm})$ and ${ }^{1} \mathrm{H}-\mathrm{NMR}$ data** indicate that (5) and (18) have a coplanar structure in the 6-10 region of the molecule.

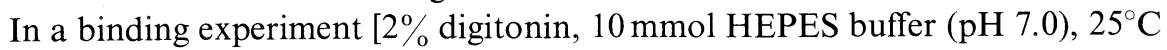
in the dark, $48 \mathrm{~h}$ ] using bovine opsin, the 9-cis-isomer (5) with a gem-dimethyl group at the 4-position gave a new bicyclic rhodopsin analog (4), whereas the other 9-cisisomer (18) with a gem-dimethyl group at the 1-position produced a negligible amount of artificial pigment***. The novel rhodopsin analog (4) showed an absorption maximum at $519 \mathrm{~nm}$ and an interesting CD spectrum (Table 1). A very weak $\beta$-CD-band in (4) suggests that the $\beta$-band in the induced $\mathrm{CD}$ of rhodopsin originates from the twist of a double bond system next to the $\beta$-ionone ring moiety. It was reported that rhodopsin analogs derived from 5,6-dihydroretinal (6) and 5,6epoxy-3-dehydroretinal (10) having saturated rings showed no $\beta$-CD-band, and retro- $\gamma$-rhodopsins (11) possessing two dissected chromophoric system composed of a planar ring exhibited the very weak $\beta$-CD-band. These results also support the conclusion that the $\beta$-CD-band of rhodopsin originates from the twist of the 6-7 single bond.

We gratefully thank Professor K. Nakanishi, Columbia University in the City of New York, for his valuable discussion.

This work was supported in part by a Grant-in-Aid (60304098) for Cooperative Research from the Ministry of Education, Science and Culture of Japan, to M.I. and T.Y.

\section{REFERENCES}

1) Yoshizawa, T., and Shichida, Y. (1982): Low-temperature circular dichroism of intermediates of rhodopsin. Methods Enzymol., 81, 634-641.

2) Fukada, Y., Shichida, Y., Yoshizawa, T., Ito, M., Kodama, A., and Tsukida, K. (1984): Studies on structure and function of rhodopsin by use of cyclopentatrienylidene 11-cislocked-rhodopsin. Biochemistry, 23, 5826-5832.

3) Sperling, W., and Rafferty, C. N. (1969): Relationship between absorption spectrum and molecular conformations of 11-cis-retinal. Nature, 224, 591-594.

4) Burke, M. J., Pratt, D. C., Faulker, T. R., and Moscowitz, A. (1973): An analysis of the absorption and circular dichroism of some visual pigments. Exp. Eye Res., 17, 557-572.

5) Ebrey, T. G., and Yoshizawa, T. (1973): The circular dichroism of rhodopsin and lumirhodopsin. Exp. Eye Res., 17, 545-556.

** Characteristic ${ }^{1} \mathrm{H}-\mathrm{NMR}$ data for (5) and (18); $\delta\left(200 \mathrm{MHz}, \mathrm{CDCl}_{3}\right),(\mathbf{5}): 2.06(3 \mathrm{H}, \mathrm{s}$, 9-Me), $2.32(3 \mathrm{H}, \mathrm{s}, 13-\mathrm{Me}), 3.20\left(2 \mathrm{H}, \mathrm{br} \mathrm{s}, 18-\mathrm{H}_{2}\right), 6.32(1 \mathrm{H}, \mathrm{d}, J=16 \mathrm{~Hz}, 12-\mathrm{H}), 6.07(1 \mathrm{H}, \mathrm{d}$, $J=12 \mathrm{~Hz}, 10-\mathrm{H}), 6.45(1 \mathrm{H}, \mathrm{s}, 7-\mathrm{H}), 7.37(1 \mathrm{H}, \mathrm{dd}, J=16,12 \mathrm{~Hz}, 11-\mathrm{H}), 10.10(1 \mathrm{H}, \mathrm{d}, J=8 \mathrm{~Hz}$, CHO). (18): $2.07(3 \mathrm{H}, \mathrm{s}, 9-\mathrm{Me}), 2.30(3 \mathrm{H}, \mathrm{s}, 13-\mathrm{Me}), 3.17\left(2 \mathrm{H}\right.$, sharp s, 18- $\left.\mathrm{H}_{2}\right), 6.32(1 \mathrm{H}, \mathrm{d}$, $J=16 \mathrm{~Hz}, 12-\mathrm{H}), 6.06(1 \mathrm{H}, \mathrm{d}, J=12 \mathrm{~Hz}, 10-\mathrm{H}), 6.63(1 \mathrm{H}, \mathrm{s}, 7-\mathrm{H}), 7.36(1 \mathrm{H}, \mathrm{dd}, J=16,12 \mathrm{~Hz}$, $11-\mathrm{H}), 10.10(1 \mathrm{H}, \mathrm{d}, J=8.5 \mathrm{~Hz}, \mathrm{CHO})$.

*** The result that (18) failed to bind with opsin was unexpected. The interaction between the analogs having the cyclopentadiene structure and the $\beta$-ionone ring binding site of opsin is now under investigation.

Vol. 34, No. 6, 1988 
6) Kropf, A., Whittenberger, B. P., Goff, S. P., and Waggoner, A. S. (1973): The spectral properties of some visual pigment analogs. Exp. Eye Res., 17, 591-606.

7) Ito, M., Hiroshima, T., Tsukida, K., Shichida, Y., and Yoshizawa, T. (1985): A novel rhodopsin analogue possessing the conformationally 6-s-cis-fixed retinylidene chromophore. J. Chem. Soc. Chem. Commun., 1443-1444.

8) MacAlpine, G. A., Raphael, R. A., Shaw, A., Taylor, A. W., and Wild, H.-J. (1976): Synthesis of the germination stimulant ( \pm )-strigol. J. Chem. Soc., Perkin Trans. I, 410416.

9) Liu, R. S. H., and Asato, A. E. (1984): Photochemistry and synthesis of stereoisomers of vitamin A. Tetrahedron, 40, 1931-1969.

10) Azuma, M., Azuma, K., and Kito, Y. (1973): Circular dichroism of visual pigment analogues containing 3-dehydroretinal and 5,6-epoxy-3-dehydroretinal as the chromophore. Biochim. Biophys. Acta, 295, 520-527.

11) Yoshizawa, T., Matsumoto, H., Horiuchi, K., Shichida, Y., Ito, M., Kodama, A., and Tsukida, K. (1987): Studies on chromophore-opsin interaction in rhodopsin by use of retro- $\gamma$-rhodopsins: formation and properties of retro- $\gamma$-rhodopsins, in Biophysical Studies of Retinal Proteins, ed. by Ebrey, T. G. et al., Univ. Illinois Press, Urbanachampaign, pp. 287-292. 